\title{
THE IMPACT OF SALINE AEROSOLS ON STUDENTS PHYSICAL PERFORMANCE
}

DOI: $\quad$ https://doi.org/10.18509/AGB.2020.07

UDC: $\quad$ 615.83:615.326]:578.087.1-057.874

\author{
Mihaela- Orlanda Antonovici ${ }^{1}$, Ion Sandu ${ }^{2,3}$, Viorica Vasilache ${ }^{4}$, \\ Andrei Victor Sandu ${ }^{3,5}$, Ioan Gabriel Sandu ${ }^{3,5}$, Cristina Carmen Stingu ${ }^{6}$
}

\author{
'Alexandru Ioan Cuza University, Faculty of Geography and Geologie, \\ Geoscience Doctoral School, Environmental Science Field, România \\ ${ }^{2}$ Alexandru Ioan Cuza University, ARHEOINVEST Interdisciplinary Platform, Romania \\ ${ }^{3}$ Romanian Inventors Forum, Romania \\ ${ }^{4}$ Alexandru Ioan Cuza University of Iasi, Interdisciplinary Research Department - Field Science, Romania \\ ${ }^{5}$ Gheorghe Asachi Technical University of Iasi, Faculty of Material Sciences and Engineering, Romania \\ ${ }^{6}$ Vasile Alecsandri University of Bacau, Department of Environmental Engineering and Mechanical Engineering, \\ Calea Marasesti, Romania
}

corresponding author:

submitted: 02.02 .2020

accepted: 24.04 .2020

published: 15.06 .2020

\begin{abstract}
The paper presents the experimental data obtained on two groups of students, one witness, in two normal classrooms and respectively in the outdoor gymnasium and another in the same type of rooms, but with halochamber regime, differentiated on gender and age, including children born in 2006 and 2007, at the age with the highest growth rate. Starting from the fact that the solions reformulated in situ act on the body through inhalation and absorption at the skin level, it offers a remedy for many conditions, as halotherapy is a complementary and / or alternative method of protecting the airways and improving the morpho-structural characteristics of the skin of the human body. An original system was used to process the experimental data regarding the evolution of the characteristics studied, expressed as a percentage increase, allowed a good highlighting of the effect of saline aerosols/solions on the morpho-structural type biometric characteristics (weight, height, thoracic perimeter), pulse and blood pressure in children, depending on age and gender. It has been shown that girls interact more strongly with solions, and register higher values for most of the studied parameters than boys.
\end{abstract}

Keywords: solions, saline anhydrous aerosols, halochamber (salt room), halo-therapy, microclimatic parameters, biometric morpho- structural and dynamic characteristics

\section{INTRODUCTION}

Saline aerosols in the form of nano dispersions in gaseous environments behave, as far as concentration levels and lifetime, in the form of trimodal Gaussian distributions: fine Aitken particles (below $50 \mu \mathrm{m}$ ), medium (between 50 and $500 \mu \mathrm{m}$ ) and coarse or large (between 500 and 1000 $\mu \mathrm{m})$ respectively [1-7]. The fine and medium ones have the stability over time depending on the active surface of the porous granules of the source of generation (diaphragm), the shape (cylindrical or parallelepiped diaphragm), size and structural profile of the diaphragm, number of generation centers, particle size and position of superficial fluorescent microcrystallites. superficial (external surface and that of the pores of the granules), the porosity of the granules, the levels of the climatic parameters and other characteristics of the gaseous environment of the halochamber [3-3]. The works elaborated in the last years within our group [3-5, 14-23] have experimentally demonstrated that the solion-type hydrated nano-aerosols, as such or doped with other halo-salts, in addition to the ability to prevent and treat diseases cardio-respiratory, osteo-muscular and psychomotor, have at certain levels of concentration beneficial effects on the development of children, in increasing the athletic performance in young sportsmen and in improving the resistance of the persons who carry out activities with intense physical effort, in severe or high performance work regimes.

For people working in severe conditions (eg. welders), the aerial metal smoke resulting from the 
welding process can be inhaled by welders, being used in studies, respiratory filters (FFR), which stop the particles from entering the airways of the workers [8]. Research has been carried out on the effect they have on relative humidity, particles composed of sodium chloride and sodium sulfate, thus it was investigated how the particle size influences the efflorescence rate and which of them nucleate faster, when the $\mathrm{NaCl}$ particles are larger than $70 \mathrm{~nm}$, the ERH decreases with decreasing dry particle sizes [9]. Therefore, in the particle size distribution of saline aerosols (Aitken nanoparticles of $\mathrm{NaCl}$ ), two subgroups are differentiated: anhydrous and hydrated ones, called solions. The first are non-symmetrical, poorly aquatized nanopolyhedrons, which by the anhydrizing effect of the membrane systems will chronicize the affections, while the solions (continuously/ dynamically reformed at atmospheric humidities greater than $85 \%$ ), with a movable glomerular structure at the level of a tissue in vivo through deliquescence will facilitate the directing of the ions to the specific channels, stimulating the membrane biochemical processes. In other words, solions have good bioactive compatibility with living tissues, activating a number of membrane processes in vivo. Moreover, they, in addition to creating

\section{EXPERIMENTAL PART}

\section{Methods and techniques used to determine the characteristics of active solions}

The characteristics of the solions during the rest periods, 50 minutes after the start and the end of the classes, were determined using two particle counters type SIBATA GT 321 and Dust Trok, an Air Ion Counter type ionometer and by the method of differential conductometry, using a patented device within our group [32]. Also, the evolution in time and work stages of the following parameters registering the main climatic factors in the classrooms were monitored, namely: temperature ( $\square \mathrm{C})$, air humidity (\% UR), atmospheric pressure $(\mathrm{mmHg})$ and lighting $(\mathrm{lx})$, using specific laboratory devices.

The study used a series of generators with diaphragms containing porous granules of $\mathrm{NaCl}$, obtained by recrystallization, at $50 \ldots 60^{\circ} \mathrm{C}$, from supersaturated solutions. Four generators were placed at the windows of two classrooms with a volume of 126 cubic meters $(7 \times 6 \times 3)$ and six in the $320 \mathrm{~m} 3(10 \times 8 \times 4)$ gyms. In order to achieve an optimal level in solions, the generators were started about 60 minutes before the start of class hours. After 50 minutes of operation, the average level of solions was determined, and then determined againat the end of the classes. For the Physical Education classes, there was a progressive program clean air environments, allow, as previously mentioned, the prevention/treatment of certain diseases and to improve the physical performance of human subjects.

Aerosol therapy (inhalation therapy) is a field of science that deals with the methods of treatment and prevention of airway disease, the efficiency of the treatment depends on the size distribution of the aerosol particles, their physical properties (density, shape, hygroscopicity, morphology).

In connection with these nanoparticles, a series of patented artificial halochambers were developed, which were experienced in the teaching activities with the students. With their help it has been shown that solions active at a certain level of concentration have a beneficial influence on the development of the young, with the female having a higher receptivity regarding the effect of improving human performances [24-31].

The paper presents the influence of solions on the development of children, aged between 12 and 15 years, in terms of the evolution of body weight, height, chest perimeter or chest thickness, for a period of 15 months. In this respect, the influence of the active residence time in the halochamber is studied, which is ten times higher than in other studies of the group $[3-5,14,15]$..

of exercises, training and games over the period of 50 minutes, twice a week, distributed on even time intervals. For the two groups of activities (normal lessons in the classroom and physical education in the school gym) there were two groups of students who performed in parallel, one group in salt rooms and another in normal classrooms or gym, using the same work schedule and the respective time intervals. The students were monitored throughout the school year, twice a week regarding the evolution of morphostructural and biometric characteristics. For each work program, the level reached by saline aerosols/solions was correlated with the average data of the biometric characteristics of the students, separated on gender [33].

\section{Selection of experimental groups of students}

The experiments were performed on two groups of students (girls and boys) from classes VI and VII, for each age category, noted by the year of birth (2006 and 2007): the reference group for outdoor or gym applications, made of the group of girls noted F0i200X ( $X=6$ and 7), with student $i$, having the year of birth 200X and the group of boys noted B0i200X, with student i, having the year of birth 
$200 \mathrm{X}$ and respectively the halochamber group formed by the group of girls noted Fhi200X having student $i$, with the year of birth 200X and the group of boys noted Bhi200X with student $\mathrm{i}$, having the year of birth $200 \mathrm{X}$, where $\mathrm{i}=1,2,3 \ldots$, represents the number of the student in the group, each group with 7 to 25 students. In order to select the students for the two experimental groups (from the halochamber and from the open air), a series of data was used according to a standard form that includes information regarding the family living conditions, the family medical history (hemophilia, diabetes mellitus, HTA, parasites , heart disease, cancer, rheumatic diseases, TB), personal physiological, pathological history (eruptive diseases, whooping cough, hepatitis, gastritis, cardiovascular, immunological, metabolic and endocrine disorders) [33].

\section{Biometric characteristics and their determination}

Within the morphometric and functional biometric examination, in order to determine the level of physical development of the subjects, a series of measurements were made, namely [33]:

- the weight, which was made with the help of the electronic scale and was expressed in kilograms;

- stature (height), which was determined with the staturometer, being expressed in centimeters;

- the thoracic perimeter, respectively the thickness of the thorax, was measured with a metric band $(100 \mathrm{~cm})$, recording two dimensions, with the thoracic perimeter in respiratory rest (the moment between inspiration and expiration) and respectively the thoracic perimeter in maximum inspiration.

\section{Processing of experimental data}

In order to facilitate the interpretation of the experimental results, the percentage increase of the

\section{RESULTS AND CONCLUSIONS}

Since the dynamics of aerosol emissions from halochambers is influenced by the environmental conditions, humidity, temperature, pressure and lighting, the determinations were made keeping the values of the parameters of the pumped air constant and monitoring the microclimate formed in the salt room. The main factor for improving and characteristic over time was used graphically. For this purpose, the biometric data were determined periodically, at $3,6,9,12,15,18,21$ and 24 months respectively for establishing the evolution of the subjects' weight and height, and for highlighting the increase of the thoracic perimeter, at 3, 6, 9, 12, 15, 18 and respectively 21 months.

Based on the recorded data, a primary table was prepared. Then the average of the values for the same period evaluated for each group of students, respectively the group of girls, noted F0m $200 \mathrm{X}$ and the group of boys, noted $\mathrm{B} 0 \mathrm{~m} 200 \mathrm{X}$, where $\mathrm{m}$ represents the arithmetic mean, and $\mathrm{X}$ - values 6 or 7 , corresponding to the year of birth. .

After this, the percentage (\%) was calculated with the evolution of the characteristic $\mathrm{C}$, compared to the start time of the experiment $(\mathrm{C} 0)$, in relation to the subsequent readings $(\mathrm{Cj})$, the period of determination being denoted by $j$, which represents the month of the year of readings, using relationship [33]:

$\mathrm{C}(\%) \mathrm{F} 0 \mathrm{~m} 200 \mathrm{X}$ or $\mathrm{C}(\%) \mathrm{B} 0 \mathrm{~m} 200 \mathrm{X}=100 \times(\mathrm{Cj}-$ $\mathrm{C} 0) / \mathrm{C} 0,(1)$

respectively:

$\mathrm{C}(\%) \mathrm{Fhm} 200 \mathrm{X}$ or $\mathrm{C}(\%) \mathrm{Bhm} 200 \mathrm{X}=100 \times(\mathrm{Cj}-$ $\mathrm{C} 0) / \mathrm{C} 0$; (2)

Finally, the graphs $\mathrm{C}(\%)=\mathrm{f}(\mathrm{t})$ are drawn, the time being in months, for the average values of the girls and boys, in the two different working conditions, taken separately (outdoors, noted in the lower right indicates " 0 " and halochamber, noted down right indicates "h"). Each biometric characteristic, taken in the study, was represented in the same coordinate system, having in order C (\%) and in the abscissa time in months.

Based on these graphs, the evolution of each group of students was appreciated and the influence of saline aerosols and reformulated solions in situ on the characteristics studied was established..

maintaining student health in our case is the sodium chloride solution, made up of nanoparticles with diameters ranging from 2 to $5 \mu \mathrm{m}$, structurally reformed from Aitken particles in a humid environment ( $\geq 65 \% \mathrm{RH})$ [34]. The results obtained for the climatic parameters and the concentrations in solions from halochamber are presented in table 1. 
Table 1. Evolution in time of the climatic characteristics of the two types of environments used in the experiment (outdoor / controlled and halochamber).

\begin{tabular}{|c|c|c|c|c|c|c|}
\hline System & Parameter & Oct 2018 & Jan 2019 & May 2019 & Aug 2019 & Nov 2019 \\
\hline & $\begin{array}{l}\mathrm{C}, \mathrm{mg} / \mathrm{m}^{3}, \\
\text { solion }\end{array}$ & 0.0 & 0.0 & 0.0 & 0.0 & 0.0 \\
\hline \multirow{4}{*}{$\begin{array}{c}\mathrm{Gym} / \\
\text { Outdoor field } \\
\text { (Witness) }\end{array}$} & $\mathrm{T}^{\circ} \mathrm{C}$ & 19 & 18 & 20 & 21 & 20 \\
\hline & $\mathrm{P}$, atm & 750 & 740 & 760 & 760 & 750 \\
\hline & UR, \% & 70 & 60 & 65 & 60 & 70 \\
\hline & $\mathrm{I}, \mathrm{lx}$ & 120 & 116 & 120 & 130 & 120 \\
\hline \multirow[t]{5}{*}{$\begin{array}{c}\text { Gym } \\
\text { (Halochamber) }\end{array}$} & $\begin{array}{l}\mathrm{C}, \mathrm{mg} / \mathrm{m}^{3}, \\
\text { solion }\end{array}$ & 0.660 & 0.665 & 0.680 & 0.670 & 0.665 \\
\hline & $\mathrm{T}^{\circ} \mathrm{C}$ & 21 & 20 & 21 & 22 & 20 \\
\hline & P,atm & 750 & 740 & 760 & 760 & 750 \\
\hline & UR, \% & 75 & 70 & 75 & 75 & 70 \\
\hline & $\mathrm{I}, \mathrm{lx}$ & 110 & 105 & 110 & 120 & 110 \\
\hline \multirow[t]{5}{*}{$\begin{array}{c}\text { Classroom I } \\
\text { (Witness) }\end{array}$} & $\begin{array}{l}\mathrm{C}, \mathrm{mg} / \mathrm{m}^{3} \text {, } \\
\text { solion }\end{array}$ & 0.0 & 0.0 & 0.0 & 0.0 & 0.0 \\
\hline & $\mathrm{T}^{\circ} \mathrm{C}$ & 21 & 22 & 22 & 22 & 21 \\
\hline & P,atm & 750 & 740 & 760 & 760 & 750 \\
\hline & UR, \% & 75 & 70 & 75 & 75 & 70 \\
\hline & $\mathrm{I}, \mathrm{lx}$ & 110 & 105 & 110 & 120 & 110 \\
\hline \multirow[t]{5}{*}{$\begin{array}{c}\text { Classroom I } \\
\text { (Halochamber) }\end{array}$} & $\begin{array}{l}\mathrm{C}, \mathrm{mg} / \mathrm{m}^{3} \text {, } \\
\text { solion }\end{array}$ & 0.860 & 0.965 & 0.980 & 0.970 & 0.865 \\
\hline & $\mathrm{T}^{\circ} \mathrm{C}$ & 21 & 22 & 22 & 22 & 21 \\
\hline & P,atm & 750 & 740 & 760 & 760 & 750 \\
\hline & UR, \% & 75 & 70 & 75 & 75 & 70 \\
\hline & $\mathrm{I}, \mathrm{lx}$ & 110 & 105 & 110 & 120 & 110 \\
\hline \multirow[t]{5}{*}{$\begin{array}{l}\text { Classroom II } \\
\text { (Witness) }\end{array}$} & $\begin{array}{l}\mathrm{C}, \mathrm{mg} / \mathrm{m}^{3}, \\
\text { solion }\end{array}$ & 0.0 & 0.0 & 0.0 & 0.0 & 0.0 \\
\hline & $\mathrm{T}^{\circ} \mathrm{C}$ & 21 & 22 & 22 & 22 & 21 \\
\hline & $\mathrm{P}, \mathrm{atm}$ & 750 & 740 & 760 & 760 & 750 \\
\hline & UR, \% & 75 & 70 & 75 & 75 & 70 \\
\hline & $\mathrm{I}, \mathrm{lx}$ & 110 & 105 & 110 & 120 & 110 \\
\hline \multirow[t]{5}{*}{$\begin{array}{c}\text { Classroom II } \\
\text { (Halochamber) }\end{array}$} & $\begin{array}{l}\mathrm{C}, \mathrm{mg} / \mathrm{m}^{3}, \\
\text { solion }\end{array}$ & 0.850 & 0.935 & 0.940 & 0.930 & 0.845 \\
\hline & $\mathrm{T}^{\circ} \mathrm{C}$ & 21 & 22 & 22 & 22 & 21 \\
\hline & P,atm & 750 & 740 & 760 & 760 & 750 \\
\hline & UR, \% & 76 & 72 & 78 & 79 & 72 \\
\hline & $\mathrm{I}, \mathrm{lx}$ & 110 & 105 & 110 & 120 & 110 \\
\hline
\end{tabular}

The data in Table 1, show the average value of the microclimate parameters and the concentration of solions in the three groups of rooms, each having a witness room and a halochamber), respectively the gymnasium (bad weather)/the sports field (good weather, witness only) and the four classrooms, two with sixth form students, born in 2006 and another two for seventh-graders, born in 2007. So, each group is composed of two classrooms, one blank, with level of solions 0.0 and the second with halochambers for the experiment. As the gym is used alternatively, 2 hours a week, on Tuesdays and Fridays, for both classes, but for different time intervals, monitoring of the three morphostructural/biometric characteristics (body weight, height and circumference of the thoracic perimeter) is made only for the period of activities in the two classrooms, the witness and the experimental one.

Figures 1-6 show the evolution charts of the three main characteristics in children (body weight, height and circumference of the thoracic perimeter). 


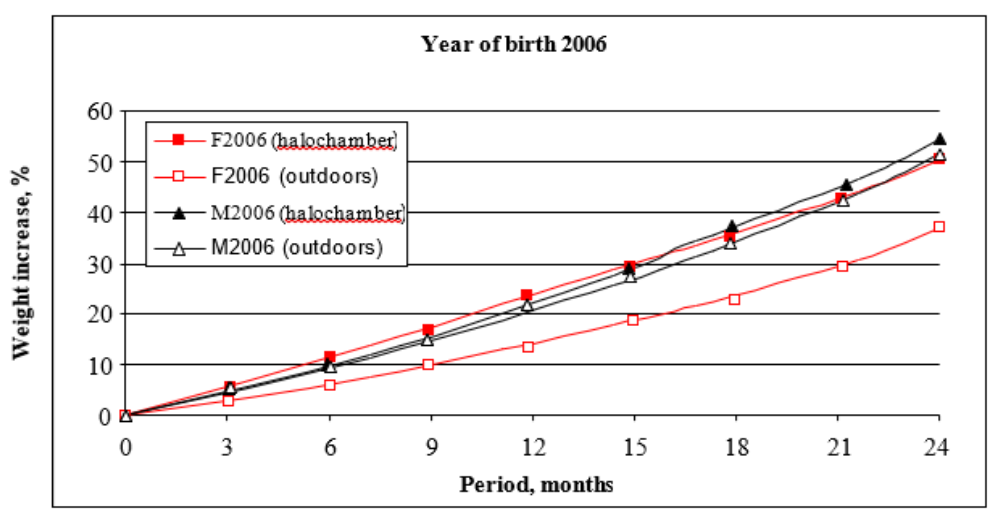

Figure 1. Evolution of body weight students born in 2006, from the two classes I and II

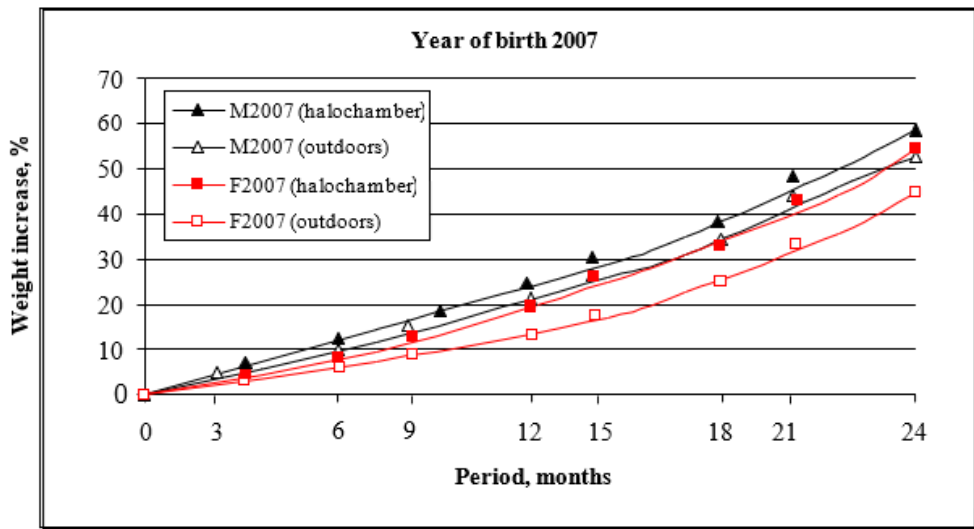

Figure 2. Evolution of body weight of students born in 2007, from the two classes I and II.

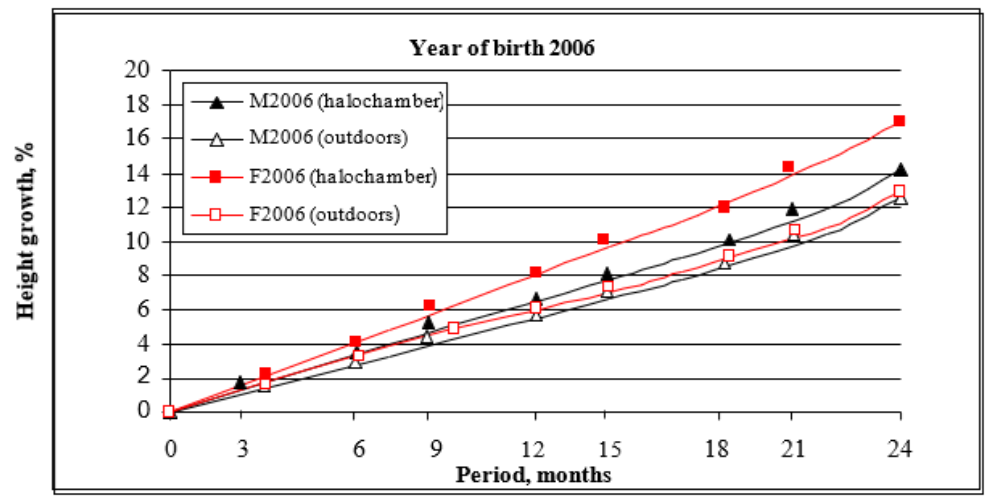

Figure 3. Evolution of students' heights, born in 2006 from the two classes I and II.

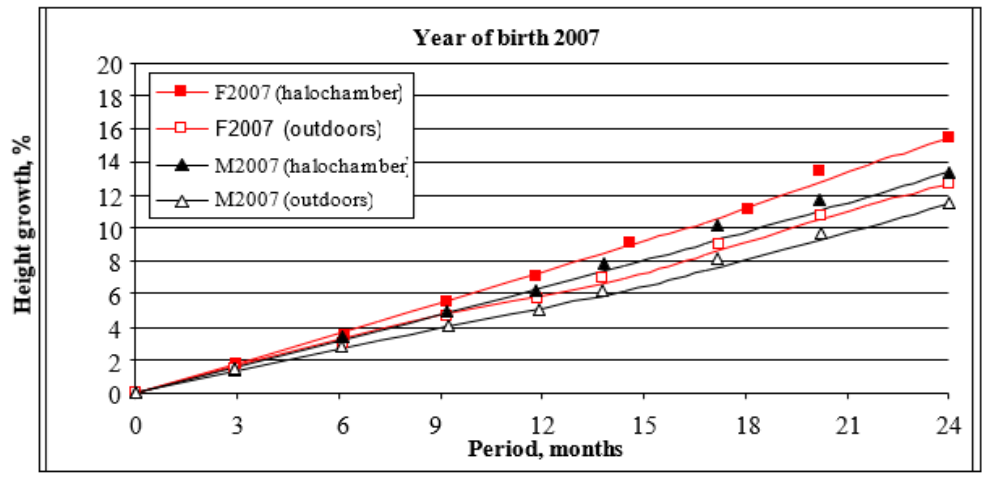

Figure 4. Evolution of students heights, born in 2007, from the two classes I and II. 


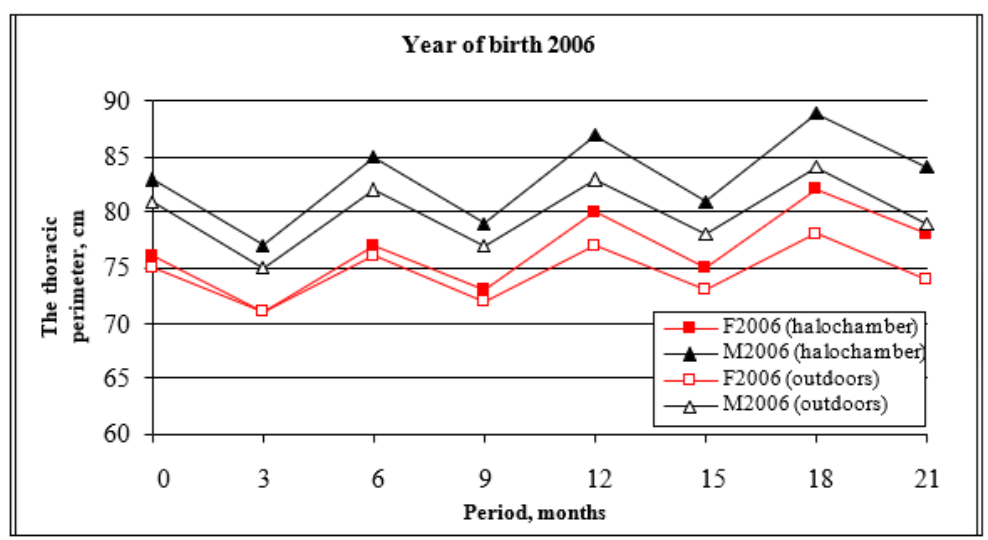

Figure 5. Evolution of the circumference of the thoracic perimeter of students, born in 2006, from the two classes I and II.

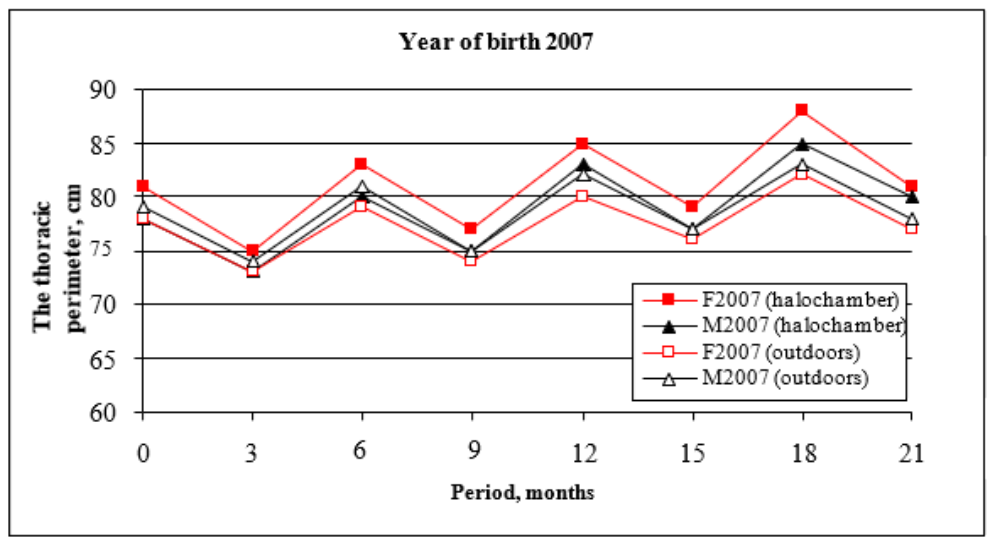

Figure 6. Evolution of the circumference of the thoracic perimeter of students, born in 2007, from the two classes I and II.

Based on the graphs in the figures above, it can be observed that for girls born in 2006 the two representative curves for weight evolution are strongly differentiated, the curve corresponding to the halochamber is much higher in the first 18 months than for the witness. On the other hand, for boys the increase in weight for the two curves (from the halochamber and from the witness) has parallel and similar evolution rates, but after 18 months it is above the development curve for girls. This effect is due to the fact that boys have a higher rate of development than girls, whereas girls are more vulnerable to the influence of aerosols.

We find the same effect for students born in 2007, with the difference that from the beginning the evolution of the weight for boys is above that corresponding to girls.

In terms of height, both for students born in 2006 and 2007, the percentage growth rate for girls is higher than for boys.

For the third characteristic, the circumference of the thoracic perimeter, the students born in 2006 have a higher percentage growth rate than for the girls, and for those born in 2007, the results parallel the halochamber curve and the one in the witness room corresponding to the girls. The average growth of the thoracic perimeter recorded in respiratory rest and in maximum inspiration (inspire) respectively under the influence of saline aerosols/solions, for the large age series presents a lower growth rate in girls than in boys, a phenomenon considered normal.

In contrast, for the younger ages, the same evolution of the size of the thoracic perimeter registers a higher growth rate in girls than in boys, and in the first 12 months the values recorded in the inspiration, both in the case of the witness groups and in the halochamber are very close, because then, the average size of the thoracic perimeter will increase more strongly in girls, than in boys, an evolution that can be explained by the genetic diversity and the existence of large differences in the quality of life of the children in the study area (rural, mountainous area with oil and forestry industry). The organization of the didactic program in the classroom and in the physical education classes was differentiated according to the lesson plan. In time, the harmonious physical development of the children was pursued (the development of the muscles, the chest, the height, the improvement of the strength and the resistance of the body, achieving a balance between the optimal weight and the height of the students). In order to reach these goals, differentiated by age, according to the 
curriculum, those physical exercises were selected from the beginning and the end of the lessons that allowed a better harmonization of the morphostructural/biometric characteristics, of which we mention: walking (variants) around the class,

\section{CONCLUSIONS}

The experimental data obtained on the groups of students, one witness, who worked in the outdoor sports hours or on the sports field (in good weather)/the gymnasium (in bad weather), respectively for the other teaching hours in two classes without aerosols and two halochamber type classes (classrooms equipped with dynamic aerosol/solion generators), the students being differentiated by the two genders and ages, including children born in 2006 and 2007, and the time spent sitting/working in the halochamber being ten times more than the one studied before [3$5,14,15]$ the following conclusions can be made:

- saline aerosols and solions reformulated in situ in humid environment respectively act on the body through inhalation and absorption at the skin level, which according to the literature offers a remedy for many conditions, halotherapy being a complementary and/or alternative method of airway protection, but and improving morpho-structural/biometric characteristics of the human body;

- the system of processing the experimental data regarding the evolution of the three morphostructural/biometric characteristics (body weight, height and circumference of the thoracic perimeter), expressed as a percentage increase, allowed a good highlighting of the effect of saline aerosols/solions on the three characteristics taken in you study, by age and gender;

- it can be observed that for the girls born in 2006 the two curves of weight gain are strongly separated, the curve corresponding to the halochamber is higher in the first 18 months than the one in the witness room. In contrast, for boys the increase in weight for the two curves (from the

halochamber and from the witness room) have parallel and similar values and close evolution rates, but after 18 months they are above the development curves in girls; this effect is due to assisted by exercises for all body segments. All the exercises were executed, in terms of effort, gradually. Students who worked in the halochamber came into contact with the solions atmosphere, both through the skin and by inhalation..

the fact that boys have a higher development rate than girls, while girls are more vulnerable to the influence of solions.

- the same effect is found for students born in 2007, with the difference that from the beginning the evolution of weight for boys is above that corresponding to girls.

- in terms of height, both for students born in 2006 and 2007 , the percentage growth rate for girls is higher than for boys.

- the third characteristic, the circumference of the thoracic perimeter, presents for the students born in 2006 a higher percentage growth rate than for the girls, and for those born in 2007 it is located between curve related to the halochamber and that of the witness room corresponding to girls.

- the increase of the average dimensions of the thoracic perimeter dimensions recorded in respiratory rest and respectively in maximum inspiration (inspire) under the influence of saline aerosols/solions, for the largest age series, presents a lower growth rate in girls than in boys, a phenomenon considered normal;

- on the other hand, for the younger series, the same evolution of the size of the thoracic perimeter registers a higher growth rate in girls than in boys, and in the first 12 months the values recorded in inspiration, both in the case of the witness and in the halochamber groups are very close, so that later, the average size of the thoracic perimeter will increase more strongly in girls, than in boys, an evolution that can be explained by the genetic diversity and the existence of large differences in the quality of life of children in the study area (rural, mountain with oil and forestry industry).

Acknowledgment: This work was supported by a grant of the Romanian Ministery of Research and Innovation, CCCDI - UEFISCDI, project number PN-III-P1-1.2 - PCCDI-2017-0239/60PCCDI 2018, within PNCDI. 


\section{Mihaela- Orlanda Antonovici et al. \\ Impact of saline aerosol on students physical performance ...}

\section{REFERENCES}

[1] Haaf W, Jaenicke R. Results of improved size distribution measurements in the Aitken range of atmospheric aerosols. J Aero Sci 11(3): 321-330, 1980.

[2] Alfoldy B, Torok S, Balashazy I, Hofmann W, Winkler Heil R. EPMA and XRF characterization of therapeutic cave aerosol particles and their deposition in the respiratory system. X-RAY Spectr., 31(5): 363-367, 2002.

[3] Sandu IG, Vasilache V, Sandu AV, Chirazi M, Honceriu C, et al. The Role of Saline Aerosols in the Prevention and Therapy of Cardio-respiratory and Osteo-muscular Afflictions. Revista de Chimie (Bucharest), Romania, 69(10): 2826-2832, 2018.

[4] Sandu I, Olariu RI, Sandu IG, Stirbu C, Pascu C, et al. Investigation of the dynamics and kinetics involved in saline aerosol generation under air erosion of pure and contaminated halide salts. J. Aerosol Sci, 81: 100-109, 2015.

[5] Sandu I, Canache M, Sandu IG, Pascu C, Sandu AV, et., al. Researches on the NaCl Saline Aerosols III. Influence of Physical Doping with other Sals on Aerosols Generations: Aerosol and Air Quality Research, 10(6): 1731-1740, (2013)

[6] Chervinskaya AV, Zilber NA. Halotherapy for treatment of respiratory diseases. J Aerosol Med, 8(3):221-232, 1995.

[7] Chervinskaya AV, Halotherapy in Controlled Salt Chamber Microclimate for Recovering Medicine, Balneol Pol Tom , 2(108): 133-141, 2007.

[8] Cho HW, Yoon CS, Lee JH, Lee SJ, Viner A, et al. Comparison of pressure drop and filtration efficiency of particulate respirators using welding fumes and sodium chloride. Ann Occup Hyg 55(6): 666-680, 2011.

[9] Gao Y, Chen SB, Yu LE . Efflorescence relative humidity of airborne sodium chloride particles: A theoretical investigation. Atmospheric Environment, 41(9): 2019-2023, 2007.

[10] Ghosal S, Hemminger JC, Bluhm H, Mun BS, Hebenstreit ELD, et al. Electron spectroscopy of aqueous solution interfaces reveals surface enhancement of halides. Science , 307(5709): 563-566, 2005.

[11] Tang P, Chan HK, Tam E, de Gruyter N, Chan J. Preparation of $\mathrm{NaCl}$ powder suitable for inhalation. Industrial \&Engineering Chemistry Research, 45(12): 4188-4192, 2006.

[12] Wang Z, King SM, Freney E, Rosenoern T, Smith ML, et al. The dynamic shape factor of sodium chloride nanoparticles as regulated by drying rate. Aerosol Sci Tech 44(11): 939-953, 2010.

[13] Sullivan RC, Moore MJK, Petters MD, Kreidenweis SM, Roberts SM, et al. Effect of chemical mixing state on the hygroscopicity and cloud nucleation properties of calcium mineral dust particles. Atmos Chem Phys, 9: 3303-3316, 2009.

[14] Sandu I, Canache M, Mihaescu T, Chirazi M, Sandu AV, et al. Influence of NaCl Aerosols on the Functional Characteristics of Children., Revista de Chimie (Bucharest), Romania, 66(1): 60-65, 2015.

[15] Sandu I, Canache M, Sandu AV, Chirazi M, Mihaescu T, et al. The influence of $\mathrm{NaCl}$ aerosols on weight and height development of children, Envi Moni Asse, 187(2): 15, 2015.

[16] Sandu I, Poruciuc A, Alexianu M, Curcă RG, Weller O. Salt and Human Health: Science, Archaeology, Ancient Texts and Traditional Practices of Eastern Romania. Mankind Quarterly, 50(3): 225-256, 2010.

[17] Ştirbu CM, Ştirbu IC, Sandu I. Impact Assessment of Saline Aerosols on Exercise Capacity of Athletes. Procedia Soci and Behavi Sci , 46: 4141-4145, 2012.

[18] Sandu I, Chirazi M, Canache M, Sandu GI, Alexeianu MT, et al. Research on NaCl saline aerosols I. Natural and artificial sources and their implications. Envi Eng and Manag J, 9(6): 881-888, 2010.

[19] Sandu I, Chirazi M, Canache M, Sandu GI, Alexeianu MT, et al. Research on NaCl saline aerosols II. New artificial halochamber characteristics. Envi Eng and Manag J , 9(8): 1105-1113, 2010.

[20] Sandu I, Alexianu M, Curcă R-G, Weller O, Pascu C. Halotherapy: From Ethnoscience to Scientific Explanations. Envil Eng and Manag J, 8(6): 1331-1338, 2009.

[21] Sandu I, Pascu C, Sandu IG, Ciobanu G, Vasile V, et al. The obtaining and characterization of $\mathrm{NaCl}$ nanocrystalline dispersions for saline-type therapeutical media. I Theoretical aspects. Revista de Chimie (Bucharest), Romania, 54: 807-812, 2003.

[22] Sandu I, Pascu C, Sandu IG, Ciobanu G, Sandu AV, et al. The obtaining and characterization of NaCl nanocrystalline dispersions for saline - type therapeutical environments. II. The in situ analysis of saline room aerosols. Revista de Chimie (Bucharest), Romania, 55(10): 791-797, 2004. 
[23] Sandu I, Pascu C, Sandu IG, Ciobanu G, Sandu AV, et al. The obtaining and characterization of $\mathrm{NaCl}$ nanocrystalline dispersions for saline - type therapeutical climate. III. The evaluation of the Salin device reliability. Revista de Chimie (Bucharest), Romania, 55(11): 971-978, 2004.

[24] Sandu I, Canache M, Chirazi M, Sandu AV, Matei PN. et al. Artificial Halochamber for Multiple Users and Reactivation Process. Patent RO128973 (B1)/2013-11-29, 2013.

[25] Sandu I, Canache M, Lupascu T, Chirazi M, Sandu AV, et al. Artificial halochamber (embodiments), process for loading and process for reactivation of used salt granules (embodiments), Patent MD4239 (B1)/2013.07.31, 2013.

[26] Sandu I, Stirbu CM, Lupascu T, Chirazi M, Stirbu CM, et al. Artificial surface halochamber. Patent MD4089 (B1)/2011.01.31, 2011.

[27] Sandu I, Stirbu CM, Chirazi M, Stirbu CM, Sandu AV, et al. Artificial halochamber for multiple users. Patent RO126285 (B1)/2011.05.30, 2011.

[28] Sandu I, Stirbu CM, Stirbu CM, Sandu AV, Vasilache V, et al. Artificial microsaline or halochamber for multiple users. Patent RO126284 (B1)/2011.05.30, 2011.

[29] Sandu I, Canache M, Sandu IG, Sandu AV, Vasilache V. Artificial halo chamber for multiple users. Patent RO126283 (B1)/2011.05.30, 2011.

[30] Sandu I, Canache M, Lupascu T, Sandu AV, Vasilache V. et al. Surface artificial halochamber. Patent MD4040 (B1)/2010.05.31, 2010.

[31] Sandu I, Stirbu CM, Lupascu T, Stirbu CM, Sandu AV. et al. Surface artificial microsalt mine. Patent MD4039 (B1)/2010.05.31, 2010.

[32] C. Pascu, I. Sandu, G. Ciobanu, I.G. Sandu, V. Vasile, O. Ciobanu, A.V. Sandu, A. Pascu. Method and Device for Determining Saline Aerosols "in situ".Patent RO122232/27.03.2009.

[33] Sandu I., Canache M., Sandu A.V., Vasilache V. Aerosolii salini în dezvoltarea copiilor. Editura Universităţii “Alexandru Ioan Cuza" Iaşi, Romania, p.195, 2015.

[34] Kanny G., Surdu O., Boulange M. Halothérapie et spéléothérapie : se soigner dans les mines de sel. Hegel, Vol 9, Nr. 1, 2019.. 